mately 1 in $10^{6}$ bacteria, may end up in the air again after collection on a respirator. Based on these experiments with $M$ tuberculosis surrogate bacteria, we conclude that $M$ tuberculosis is unlikely ever to become an infectious problem in the air again, once it is removed by a respirator.

\section{REFERENCES}

1. Centers for Disease Control and Prevention. Tuberculosis morbidityUnited States, 1992. MMWR 1993;42:696-705.

2. Centers for Disease Control and Prevention. Guidelines for preventing the transmission of Mycobacterium tuberculosis in health-care facilities. MMWR 1994;43:1-132.

3. Fennelly K. Personal respiratory protection against Mycobacterium tuberculosis. Clin Chest Med 1997;18:1-17.

4. Qian Y, Willeke K, Grinshpun S, Donnelly J. Performance of N95 respirators: filtration efficiency for airborne bacteria and solid particles. $A m$ Ind Hyg Assoc J 1998;59:128-132.

5. Willeke K, Qian Y. Tuberculosis control through respirator wear: performance of NIOSH-regulated respirators. Am J Infect Control 1998;26:139-142.

6. Qian Y, Willeke K, Grinshpun S, Donnelly J. Performance of N95 respirators: reaerosolization of bacteria and solid particles. Am Ind Hyg Assoc $J$ 1997a;58:876-880

7. Rivera P, Louther J, Mohr J, Campbell A, DeHovitz J, and Sepkowitz KA. Does a cheaper mask save money? The cost implementing a respiratory personal protective equipment program. Infect Control Hosp Epidemiol 1997;18:24-27.
8. Wayne LG. Cultivation of Mycobacterium tuberculosis for research purposes. In: Bloom BR, ed. Tuberculosis. Pathogenesis, Protection, and Control. Washington, DC: American Society for Microbiology Press; 1994:73-83.

9. Freeman BA. Burrows Textbook of Microbiology. Philadelphia, PA: WB Saunders Co; 1985:610-611.

10. Respiratory protection devices: final rule and notice. (42 CFR Part 84) Federal Register June 8, 1995;60(110):30336-30404.

11. Greenspan L. Humidity fixed points of binary saturated aqueous solutions. Journal of Research of the National Bureau of Standards-A. Physics and Chemistry 1977;81A:89-96.

12. Nolte FS, Metchok B. Mycobacterium. In: Murray PR, Baron EJ, Pfaller MA, Tenover FC, Yolken RH, eds. Clinical Microbiology. Washington, DC: American Society for Microbiology Press; 1995:400-437.

13. Schafer MP, Fernback JE, Jensen PA. Sampling and analytical method development for qualitative assessment of airborne mycobacterial species of the Mycobacterium tuberculosis complex. Am Ind Hyg Assoc J 1998;59:540-546.

14. Qian Y, Willeke K, Ulevicius V, Grinshpun S. Particle reentrainment from fibrous filters. Aerosol Science and Technology 1997b;27:394-404.

15. Afonka D. Saliva and Its Relation to Oral Health. Montgomery, AL: Paragon Press; 1961:40-43.

16. Barnhart S, Sheppard L, Beaudet N, Stover B, Balmes J. Tuberculosis in health care settings and the estimated benefits of engineering controls and respiratory protection. J Occup Environ Med 1997;39:849-854.

17. Berlin OGW. Mycobacteria. In: Baron EJ, Finegold SM, eds. Bailey \& Scott's Diagnostic Microbiology. Toronto, Ontario, Canada: The C.V. Mosby Company; 1990:597-640.

\title{
Ventilator-Associated Pneumonia: Role of Anaerobes
}

Gina Pugliese, RN, MS

Martin S. Favero, PhD

Aspiration of oropharyngeal material, with its high concentration of anaerobic bacteria, has been implicated in the pathogenesis of both ventilator-associated pneumonia (VAP) and aspiration pneumonitis (AP). Consequently, patients with these disorders usually are treated with antimicrobial agents with anaerobic activity. Malik and coworkers from St Vincent Hospital, Worcester, Massachusetts, conducted a study to determine the incidence of anaerobic bacteria in patients with VAP and AP. Sequential blind protected-specimen brush (PSB) sampling was conducted in 143 patients with 185 episodes of suspected VAP and 25 patients with AP who required mechanical ventilation. Quantitative aerobic and anaerobic cultures were performed on all specimens.

Using predefined criteria, bacterial pneumonia was diagnosed in 63 of 185 suspected VAP episodes (34\%) and 12 of 25 patients with AP (48\%). At least one dose of an antibiotic was given in the 24 hours prior to bacteriologic sampling in 106 suspected VAP episodes (57\%) and in 12 patients with AP (48\%). More than one pathogen was isolated from 11 VAP and $4 \mathrm{AP}$ patients. Pseudomonas aeruginosa, Staphylococcus aureus, and enteric gram-negative organisms were isolated most frequently from patients with VAP. In the patients with AP, enteric gram-negative organisms were isolated in patients with gastrointestinal disorders, and Streptococcus pneumoniae and Haemophilus influenzae predominated in patients with communityacquired aspiration.

Only one anaerobic organism was isolated from the entire group of patients; Veillonella paravula was iso- lated from a blind PSB specimen in a patient with suspected aspiration pneumonia.

The authors conclude that, despite painstaking efforts, they were able to isolate only one nonpathogenic anaerobic organism from this group of patients. The spectrum of aerobes in patients with VAP was similar to that reported in the literature. The organisms found in patients with AP was a reflection of the organisms likely to colonize the oropharynx. The use of antibiotics with anaerobic coverage may not be necessary in patients with suspected VAP and AP. Furthermore, penicillin $G$ and clindamycin may not be the antibiotics of choice in patients with AP.

FROM: Marik PE, Careau P. The role of anaerobes in patients with ventilator-associated pneumonia and aspiration pneumonia: a prospective study. Chest 1999;115:178-183. 